\title{
Synthesis and Preliminary Kinetic Study of 5-fluorouracil Derivatives for Targeting Colon Tumor
}

\author{
Mohammed H. Mohammed ${ }^{1}$, Firas Aziz Rahi ${ }^{2}$, Hasanain Amer Naji ${ }^{3}$ \\ ${ }^{1}$ Department of Pharmaceutical Chemistry, Collage of pharmacy, University of Baghdad, Baghdad, Iraq. \\ ${ }^{2}$ Department of Pharmaceutics, Collage of Pharmacy, University of Al-Mustansiriyah, Baghdad, Iraq. \\ ${ }^{3}$ Department of Pharmaceutical Chemistry, Collage of Pharmacy, University of Al-Mustansiriyah, Baghdad, \\ Iraq. \\ *Author to whom correspondence should be addressed; E-Mail: hasanainaltaweel@gmail.com
}

\begin{abstract}
5-Fluorouracil (5-FU) is used widely as an anticancer drug to treat solid cancers, such as colon, breast, rectal, and pancreatic cancers; although it's clinical application is greatly limited by its short plasma half-life, poor tumor affinity, myelosuppression, and gastrointestinal toxicity. To tackle these problems, numerous modifications of the 5- Fu structure have been performed. Thus, 5-Fu as possible colon specific prodrugs were synthesized in which 5-Fu is attached to amino acids (alanine \& phenylalanine) using succinate group as a spacer via amide or ester bond. An approach to improve the properties of 5-fluorouracil is the chemical transformation into bioreversible derivatives (prodrugs) which are converted to the parent drug by enzymatic and / or chemical hydrolysis. The synthesis of the target compounds were accomplished following multistep reaction procedures, the chemical reaction followed up and the purity of the products were checked by TLC.

The structures of the final compounds were confirmed by their melting points, infrared spectroscopy and ${ }^{1} \mathrm{H}$-NMR spectra. The hydrolysis of compounds III, IV, V, and VI in aqueous buffer solutions of pH 1.2 and pH 7.4 were studied.

Compounds III, IV, V and VI had enough stability at $\mathrm{pH} 1.2(\mathrm{t}=429.874 \mathrm{~min}, \mathrm{t}=429.874 \mathrm{~min}$, $\mathrm{t}=334.336 \mathrm{~min}$ and $\mathrm{t}$ $=376.139 \mathrm{~min}$ respectively) and at $\mathrm{pH} 7.4(\mathrm{t}=601.823 \mathrm{~min}, \mathrm{t}=601.823 \mathrm{~min}, \mathrm{t}=429.874 \mathrm{~min}$ and $\mathrm{t}=501.519$ min respectively); expecting that hydrolysis of these compounds by microbial enzymes in the colon will deliver 5 -fluorouracil spontaneously.
\end{abstract}

\section{Indexing terms/Keywords}

5-fluorouracil; colon specific prodrug ; amino acids; kinetic study.

\section{Academic Discipline And Sub-Disciplines}

Pharmaceutical chemistry

\section{SUBJECT CLASSIFICATION}

Heterocyclic compounds

\section{TYPE (METHOD/APPROACH)}

Synthesis, characterization and kinetic study

\section{Council for Innovative Research}

Peer Review Research Publishing System

\section{Journal: Journal of Advances in Chemistry}

\author{
Vol. 7, No. 1 \\ editor@cirworld.com




\section{Introduction}

Colon cancer is the second cause of cancer related deaths in the world. Although improvements have been made in surgical techniques and in chemotherapies, the survival rate is still low [1]. 5-fluorouracil is an antimetabolite of the pyrimidine analogue type, which is frequently used for treating solid tumors, such as colorectal, gastric tract, and liver carcinomas [2, 3].

However, the clinical applications of 5-FU are greatly limited by its short plasma half-life, poor tumor affinity, myelosuppression, and strong intestinal toxicity. To tackle these problems, numerous modifications of the 5- Fu structure have been performed, thus, a series of 5-Fu prodrugs in which 5-Fu is attached to amino acids, peptides, phospholipids, and polymers have been reported [4-7].

The term "prodrug", first introduced by Albert, refers to a chemically modified form of a drug [8] that is devoid of pharmacological activity, but that can be converted to the active form of the drug in a biological system, where it exerts the desired action. This strategy can improve the limitations associated with the effective transport into tumor cells, catabolic inactivation before the cytotoxic entity can reach the tumor, and short plasma half-1ife [9, 10].

As the site of drug absorption, the colon holds several drawbacks, such as small surface area, low fluidity of the lipid membrane, existence of tighter junction compared to the small intestine, low motility, and high viscosity of intestinal contents. On the other hand, long transit time, low proteolytic activity, and responsiveness to the action of absorption enhancers are the positive aspects of the large intestine as the site of drug absorption compared to the small intestine [11].

The objective of the colon-targeted drug delivery is to avoid absorption and degradation of drugs in the upper Gl tract allowing them act site-specifically in the colon and this achieved by various approaches such as $\mathrm{pH}$ dependent utilizing the changes in $\mathrm{pH}$ along the $\mathrm{Gl}$ tract [12], coated dosage forms [13], time-controlled release systems [14], pressure-controlled colon delivery systems [15], coating drugs with bacterially degradable polymer [16] and prodrug based drug delivery system [17]. The colonic drug delivery systems are mainly based on degradation of a prodrug by microorganisms of the colon flora [18] and colonic enzymes [19]

To design a colon-specific prodrug, a parent drug is usually linked to a nonabsorbable carrier such as a polymeric matrix or a hydrophilic small molecule to prevent the absorption of the colon-specific prodrug in the upper intestine [20].

Ho et al. [21] reported that the liver has the highest dihydrouracil dehydrogenase activity with minimal activity in the colon and colon tumor. These studies suggest that bioactivation of 5-FU to 5-fluoro-2-deoxyuridine is most active and bioinactivation of 5-FU to dihydro-5-FU is the least active in colon tumor. If 5-FU is delivered specifically to colon, the active metabolite of 5-FU should be most available in colon tumor, and the systemic side effects of 5 -FU will be minimized compared with oral administration.

Spacer or linkers can be used if the desired prodrug promoiety cannot be attached directly to the parent molecule due to a sterical hindrance or functional properties of the parent drug. The spacers increase the distance between the parent molecule and the promoiety and are usually cleaved spontaneously after the enzymatic or chemical decomposition of the prodrug bond between the promoiety and the spacer [22].

\section{EXPERIMENTAL PROCEDURE}

\section{Synthesis of methyl ester hydrochlorides of L-phenylalanine and L-Alanine:}

A suspension of L-Phenylalanine $(9 \mathrm{mmole})$ dissolved in $(15 \mathrm{~mL})$ of absolute methanol, was cooled down to $-15{ }^{0} \mathrm{C}$ then thionyl chloride was added drop wise $(9 \mathrm{mmole})$, (the temperature should be keep below $-10^{\circ} \mathrm{C}$ ), the reaction mixture was left at $40^{\circ} \mathrm{C}$ for $1 \mathrm{hr}$, then refluxed for $4 \mathrm{hr}$ and left at room temperature overnight, , It was titrated with $20 \mathrm{ml}$ portion of cold ether at $0{ }^{\circ} \mathrm{C}$ until the excess of dimethyl sulphate was removed, the excess solvent was evaporated to dryness under vacuum, re-crystallize the product from methanol-petroleum ether to get pure L-Phenylalanine methyl ester $\mathrm{HCl}$. The same procedure was followed to synthesize L-Alanine methyl ester $\mathrm{HCl}$ [23].

\section{(S)-methyl-2-amino-3-phenylpropanoate hydrochloride (A).}

As White crystal (87\%yield); m.p.160 $\mathrm{c}^{\circ}$. R $\mathrm{R}$ value=0.65. IR 3425-2623of $\left(\mathrm{NH}_{3}{ }^{+} \mathrm{Cl}^{-}\right), 1747(\mathrm{C}=\mathrm{O})$ of ester, 1629 asym. bending of $\left(\mathrm{NH}_{3}\right), 1242$ and $1145(\mathrm{C}-\mathrm{O}-\mathrm{C}) \mathrm{cm}^{-1}, 742$ and $702(\mathrm{C}-\mathrm{H})$ out of plane bending vibration of monosubstituted benzene.

\section{(S)-methyl 2-amino propanoate hydrochloride (B).}

As White crystal (82\%yield); m.p. $120 \mathrm{c}^{\circ}$. Rfvalue=0.7. IR 3439-2700 $\left(\mathrm{NH}_{3}{ }^{+} \mathrm{Cl}^{-}\right), 1741(\mathrm{C}=\mathrm{O})$ of ester, 1618 bending of $\left(\mathrm{NH}_{3}\right), 1506(\mathrm{C}=\mathrm{C})$ aromatic, 1253 and $1199(\mathrm{C}-\mathrm{O}-\mathrm{C}) \mathrm{cm}^{-1}$.

\section{Synthesis of Intermediate (I):}

L-Phenylalanine methyl ester $\mathrm{HCl}(2 \mathrm{mmole})$ was treated with $(2 \mathrm{mmole})$ of succinic anhydride in tetrahydrofuran and $(2 \mathrm{mmole})$ of triethylamine at room temperature for $10 \mathrm{~min}$. The precipitate was filtered and dried without further purification to get Intermediate (IA). The same procedure was followed with L-Alanine methyl ester $\mathrm{HCl}$ to synthesize Intermediate (IB) [24]. 
(S)-4-(1-methoxy-1-oxo-3-phenylpropan-2-yl amino)-4-oxobutanoic acid Intermediate (IA)

As white powder (75\%yield); m.p. $210-212^{\circ} \mathrm{C}$ decompose. $\mathrm{R}_{\mathrm{f}}$ value $=0.75, \mathrm{IR}\left(\mathrm{KBr} \mathrm{cm}^{-1}\right) 3440 \mathrm{NH}$ of $2^{0}$ amide, $2500-3000 \mathrm{OH}$ str. vibr., 2976, 2941(C-H) of $\mathrm{CH} 3$ and $\mathrm{CH} 2,1745$ broad $(\mathrm{C}=\mathrm{O})$ of ester and acid, $1653(\mathrm{C}=\mathrm{O})$ of $2^{0}$ amide, $1539(\mathrm{~N}-\mathrm{H})$ bending of $2^{0}$ amide, $1477(\mathrm{C}=\mathrm{C})$ of benzene, $1442 \& 1394(\mathrm{C}-\mathrm{H})$ bend of $\mathrm{CH} 2$ \& $\mathrm{CH} 3,1172(\mathrm{C}-\mathrm{O}), 1240$ asym.(C-O-C), $750 \& 702(\mathrm{C}-\mathrm{H})$ out of plane bending vibration of monosubstituted benzene.

\section{(S)-4-(1-methoxy-1-oxopropan-2-yl amino)-4-oxobutanoic acid Intermediate (IB)}

As white powder (70\%yield); m.p. $198-200^{\circ} \mathrm{C}$ decompose. $\mathrm{R}_{\mathrm{f}}$ value $=0.79, \mathrm{IR}\left(\mathrm{KBr} \mathrm{cm}^{-1}\right) 3381 \mathrm{NH}$ of $2^{0}$ amide, $2500-3000 \mathrm{OH}$ str. vibr. , 2978, $2941(\mathrm{C}-\mathrm{H})$ of $\mathrm{CH} 3 \& \mathrm{CH} 2,1734(\mathrm{C}=\mathrm{O})$ stretching vibration of ester and acid, $1622(\mathrm{C}=\mathrm{O})$ str. of $2^{0}$ amide, $1593(\mathrm{~N}-\mathrm{H})$ bending of $2^{0}$ amide, $1448,1400 \& 1363(\mathrm{C}-\mathrm{H})$ bend of $\mathrm{CH} 3 \& \mathrm{CH} 2,1170(\mathrm{C}-\mathrm{O}), 1232$ asym.(C-O-C).

\section{Synthesis of Intermediate (II):}

A suspension of intermediate (IA) $(2 \mathrm{mmole}, 0.56 \mathrm{~g})$ dissolved in $(10 \mathrm{ml})$ of dry chloroform, was cooled down to $15^{\circ} \mathrm{C}$ then thionyl chloride $(2 \mathrm{mmole}, 0.15 \mathrm{~mL})$ was added slowly to it. The mixture was refluxed for $4 \mathrm{hr}$ at $60-70^{\circ} \mathrm{C}$ with continuous stirring. Then evaporate the excess solvent by using rotary evaporator. The viscous liquid was slowly added drop wise into a beaker contain of 2,4-dinitrophenol $(2 \mathrm{mmole}, 0.368 \mathrm{~g})$ dissolved in $(5 \mathrm{ml})$ of dry chloroform and triethylamine (2mmole, $0.28 \mathrm{ml}$ ) for $1 \mathrm{hr}$ on an ice bath, then continuous stirring overnight at room temperature. The solid that separated out was filtered off and washed with dry chloroform to give Intermediate (IIC). The same procedure was followed with Intermediate (IB) to give Intermediate (IID) [25].

\section{(S)-2,4-dinitrophenyl4-(1-methoxy-1-oxo-3-phenylpropan-2-yl amino)-4-oxobutanoate. Intermediate (IIC)}

As yellowish powder (62\%yield); m.p. $77-78^{\circ} \mathrm{C} . \mathrm{R}_{\mathrm{f}}$ value $=0.64, \mathrm{IR}\left(\mathrm{KBr} \mathrm{cm}{ }^{-1}\right) 3269(\mathrm{~N}-\mathrm{H})$ of $2^{0}$ amide, $3109(\mathrm{C}-\mathrm{H})$ of aromatic, 2978, $2945(\mathrm{C}-\mathrm{H})$ of $\mathrm{CH} 3 \& \mathrm{CH} 2,1743 \& 1710(\mathrm{C}=\mathrm{O})$ of ester, $1626(\mathrm{C}=\mathrm{O})$ of $2^{\circ}$ amide, $1597(\mathrm{~N}-\mathrm{H})$ bending of $2^{0}$ amide , $1479(\mathrm{C}=\mathrm{C})$ of aromatic, 1537 (NO2)anti symm., 1340 (NO2)symm., 1178 (C-O) , 1255 asym. (C-O-C), 1437\&1398 (C$\mathrm{H})$ bend of $\mathrm{CH} 3 \& \mathrm{CH} 2$.

(S)-2,4-dinitrophenyl4-(1-methoxy-1-oxopropan-2-ylamino)-4-oxobutanoate. Intermediate (IID)

As brownish powder (65\%yield);m.p. $68-70^{\circ} \mathrm{C} . \mathrm{R}_{\mathrm{f}}$ alue $=0.57, \mathrm{IR}\left(\mathrm{KBr} \mathrm{cm}^{-1}\right) 3269(\mathrm{~N}-\mathrm{H})$ of $2^{0}$ amide, 3107 (C-H) of aromatic, 2976, $2939(\mathrm{C}-\mathrm{H})$ of $\mathrm{CH} 3 \& \mathrm{CH} 2,1739(\mathrm{C}=\mathrm{O})$ stretching vibration of ester, $1626(\mathrm{C}=\mathrm{O})$ of $2^{\circ}$ amide, $1599(\mathrm{~N}-\mathrm{H})$ bending of $2^{0}$ amide, $1477(\mathrm{C}=\mathrm{C})$ of aromatic, 1537 (NO2) anti symm. , 1340 (NO2) symm., 1180 (C-O), 1257 asymm. (C-O-C), $1435 \& 1394(\mathrm{C}-\mathrm{H})$ bend of $\mathrm{CH} 3 \& \mathrm{CH} 2$.

\section{Synthesis of compound (III) \& (IV):}

A suspension of intermediate (IA) (2mmole, $0.56 \mathrm{~g})$ dissolved in $(10 \mathrm{ml})$ of dry chloroform, and was cooled down to $-15^{\circ} \mathrm{C}$ then thionyl chloride $(2 \mathrm{mmole}, 0.15 \mathrm{~mL})$ was added slowly to it. The mixture was refluxed for $4 \mathrm{hr}$ at $60-70^{\circ} \mathrm{C}$ with continuous stirring. Then evaporate the excess solvent by using rotary evaporator. The viscous liquid was slowly added drop wise into a beaker contain 5 -fluorouracil $(2 \mathrm{mmole}, 0.26 \mathrm{~g})$ dissolved in a dry 1,4 dioxane $(5 \mathrm{~mL})$ and triethylamine ( $2 \mathrm{mmole}, 0.28 \mathrm{ml}$ ) for $1 \mathrm{hr}$ on an ice bath, then stirring overnight at room temperature. The obtained suspension was filtered and the filtrate was washed with distilled water $(20 \mathrm{ml})$, dried with anhydrous magnesium sulfate and the solvent was evaporated by vacuum. The obtained compound was crystallized from diethyl ether-petroleum ether to give compound (III). The same procedure was followed with Intermediate (IB) to give compound (IV) [26].

\section{Methyl2-(4-(5-fluoro-2,4-dioxo-3,4-dihydropyrimidin-1(2H)-yl)-4-oxobutanamido)-3-phenylpropanoate. Compound} (III)

As white powder (77\%yield);m.p. $175-176^{\circ} \mathrm{C} . \mathrm{R}_{\mathrm{f}}$ value $=0.82, \mathrm{IR}\left(\mathrm{KBr} \mathrm{cm}{ }^{-1}\right) \quad 3263(\mathrm{~N}-\mathrm{H})$ of $2^{0}$ amide, $3142(\mathrm{~N}-\mathrm{H})$ of pyrimidine, $3059(\mathrm{C}-\mathrm{H})$ of aromatic , 2987 \& $2827(\mathrm{C}-\mathrm{H})$ of $\mathrm{CH} 3 \& \mathrm{CH} 2,1718,1479 \& 1394 \mathrm{NH}(\mathrm{C}=\mathrm{O})-\mathrm{C}=\mathrm{C}$-amide I, II and III (str. vibr.) of uracil and $\mathrm{C}=\mathrm{C}$ of benzene ring, $1668(\mathrm{C}=\mathrm{O})$ of $2^{0}$ amide, $1247(\mathrm{C}-\mathrm{F}) 1213$ asym. $(\mathrm{C}-\mathrm{O}-\mathrm{C}), 1440(\mathrm{C}-\mathrm{H})$ bend of $\mathrm{CH} 3$ \& $\mathrm{CH} 2,1170(\mathrm{C}-\mathrm{O}), 750$ and $715(\mathrm{C}-\mathrm{H})$ out of plane bending vibration of monosubstituted benzene. ${ }^{1} \mathrm{H}-\mathrm{NMR}(300 \mathrm{MZ}$, DMSO- $\left.\mathrm{d}_{6}\right): 11.8\left(1 \mathrm{H}, \mathrm{NH}^{*}\right.$ of $\left.5-\mathrm{FU}\right), 10.3\left(1 \mathrm{H}, \mathrm{NH}^{*}\right.$ of $\left.\mathrm{CONH}\right), 8.413\left(1 \mathrm{H}, \mathrm{CH}^{*}\right.$ of $\left.\mathrm{FC}=\mathrm{CH}\right), 7.587-6.135\left(5 \mathrm{H}^{*} \mathrm{Ar}-\mathrm{H}^{*}\right)$, $4.558\left(1 \mathrm{H}, \mathrm{CH}^{*}\right.$ of $\left.\mathrm{CHNHCO}\right), 3.165\left(3 \mathrm{H}, \mathrm{OCH}_{3}^{*}\right), 2.888-2.867\left(2 \mathrm{H}, \mathrm{CH}_{2}^{*} \mathrm{Ar}\right), 1.009-0.987\left(4 \mathrm{H}_{,} \mathrm{CH}_{2}^{*} \mathrm{CH}_{2}^{*}\right)$.

\section{Methyl2-(4-(5-fluoro-2,4-dioxo-3,4-dihydropyrimidin-1(2H)-yl)-4-oxobutanamido)-3-propanoate. Compound (IV)}

As white powder (80\%yield);m.p. $164-166^{\circ} \mathrm{C} . \mathrm{R}_{\mathrm{f}} \mathrm{value}=0.8, \mathrm{IR}\left(\mathrm{KBr} \mathrm{cm}{ }^{-1}\right) 3136(\mathrm{~N}-\mathrm{H})$ of $2^{0}$ amide,3064(N-H) of pyrimidine, 2978, $2937(\mathrm{C}-\mathrm{H})$ of $\mathrm{CH} 3 \& \mathrm{CH} 2,1718,1479 \& 1394 \mathrm{NH}(\mathrm{C}=\mathrm{O})-\mathrm{C}=\mathrm{C}$-amide I, II, and III (str.vib.) of uracil, 1668 (C=O of 2

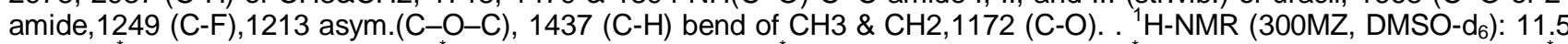
$\left(1 \mathrm{H}, \mathrm{NH}^{*}\right.$ of $\left.5-\mathrm{FU}\right),{ }_{*} 10.6\left(1 \mathrm{H}, \mathrm{NH}^{*}\right.$ of $\left.\mathrm{CONH}\right), 7.75\left(1 \mathrm{H}, \mathrm{CH}^{*}\right.$ of $\left.\mathrm{FC}=\mathrm{CH}\right), 3.68\left(1 \mathrm{H}, \mathrm{CH}^{*}\right.$ of $\left.\mathrm{CHNHCO}\right), 3.17\left(3 \mathrm{H}, \mathrm{OCH}_{3}^{*}\right)$, 1.37-1.18 $\left(7 \mathrm{H}, \mathrm{CH}_{2}{ }^{*} \mathrm{CH}_{2}{ }^{*}, \mathrm{CCH}_{3}^{*}\right)$.

\section{Synthesis of Compound (V) \& (VI):}

The reaction of Intermediate (IIC) ( 1 mmole, $0.446 \mathrm{~g}$ ) and 5-fluorouracil as sodium salt (2mmole, $0.306 \mathrm{~g}$ ) in absolute ethanol $(10 \mathrm{ml})$ was refluxed for three hours at $65^{\circ} \mathrm{C}$. The formed precipitate was filtered, washed with cold ethanol and recrystallized from ethanol as a pale yellow crystal of compound (V). The same procedure was followed with Intermediate (IID) to give pale brown crystals of compound (VI) [27]. 


\section{5-fluoro-6-oxo-1,6-dihydropyrimidine-2-yl4(1-methoxy-1-oxo-3-phenylpropan-2-ylamino)-4-oxobutanoate. Compound (V)}

As pale yellow powder (60\%yield);m.p. $129-130^{\circ} \mathrm{C} \cdot \mathrm{R}_{\mathrm{f}}$ value $=0.7$, IR $\left(\mathrm{KBr} \mathrm{cm}{ }^{-1}\right) 3128(\mathrm{~N}-\mathrm{H})$ of $2^{0}$ amide,3068(N-H) of pyrimidine, 2982, 2937\& $2825(\mathrm{C}-\mathrm{H})$ of $\mathrm{CH} 3 \& \mathrm{CH} 2,1724,1483$ \& $1396 \mathrm{NH}(\mathrm{C}=\mathrm{O})-\mathrm{C}=\mathrm{C}$-amide I, II, and III (str.vib.) of uracil and $\mathrm{C}=\mathrm{C}$ of benzene ring, $1664(\mathrm{C}=\mathrm{O})$ of $2^{0}$ amide, $1247(\mathrm{C}-\mathrm{F}), 1176$ asymm. $(\mathrm{C}-\mathrm{O}-\mathrm{C}), 1435$ \& 1336(C-H) bend of $\mathrm{CH} 3$ $\& \mathrm{CH} 2,1128(\mathrm{C}-\mathrm{O}), 752$ and $719(\mathrm{C}-\mathrm{H})$ out of plane bending vibration of monosubstituted benzene. ${ }^{1} \mathrm{H}-\mathrm{NMR}(300 \mathrm{MZ}$, DMSO- $\left.d_{6}\right): 11.30\left(1 \mathrm{H}, \mathrm{NH}^{*}\right.$ of $\left.5-\mathrm{FU}\right), 10.4\left(1 \mathrm{H}, \mathrm{NH}^{*}\right.$ of $\left.\mathrm{CONH}\right), 8.416\left(1 \mathrm{H}, \mathrm{CH}^{*}\right.$ of $\left.\mathrm{FC}=\mathrm{CH}\right), 7.584-6.118\left(5 \mathrm{H}, \mathrm{Ar}-\mathrm{H}^{*}\right)$, $4.286\left(1 \mathrm{H}, \mathrm{CH}^{*}\right.$ of $\left.\mathrm{CHNHCO}\right), 3.162\left(3 \mathrm{H}, \mathrm{OCH}_{3}^{*}\right), 2.851-2.827\left(2 \mathrm{H}, \mathrm{CH}_{2}^{*}-\mathrm{A} \mathrm{r}\right), 1.018-0.972\left(4 \mathrm{H}_{2} \mathrm{CH}_{2}^{*} \mathrm{CH}_{2}^{*}\right)$.

\section{5-fluoro-6-oxo-1,6-dihydropyrimidine-2-yl4(1-methoxy-1-oxopropan-2-ylamino)-4-oxobutanoate. Compound (VI)}

As pale brown powder (55\%yield); m.p. $140-142^{\circ} \mathrm{C} . \mathrm{R}_{\mathrm{f}}$ alue $=0.77, \mathrm{IR}\left(\mathrm{KBr} \mathrm{cm}^{-1}\right) 3132(\mathrm{~N}-\mathrm{H})$ of $2^{0}$ amide,3066(N-H) of pyrimidine, 2980,2937(C-H) of $\mathrm{CH} 3 \& \mathrm{CH} 2,1724,1483 \& 1396 \mathrm{NH}(\mathrm{C}=\mathrm{O})-\mathrm{C}=\mathrm{C}$-amide I, II, and III (str.vib.) of uracil,1662 $(\mathrm{C}=\mathrm{O})$ of $2^{0}$ amide,1247 (C-F), 1176 asymm. (C-O-C), 1435 \& 1325(C-H) bend of $\mathrm{CH} 3$ \& $\mathrm{CH} 2,1078(\mathrm{C}-\mathrm{O}) .{ }^{1} \mathrm{H}-\mathrm{NMR}$ $\left(300 \mathrm{MZ}, \mathrm{DMSO}-\mathrm{d}_{6}\right): 11.50\left(1 \mathrm{H}, \mathrm{NH}^{*}\right.$ of $\left.5-\mathrm{FU}\right), 10.6\left(1 \mathrm{H}, \mathrm{NH}^{*}\right.$ of $\left.\mathrm{CONH}\right), 7.75\left(1 \mathrm{H}, \mathrm{CH}^{*}\right.$ of $\left.\mathrm{FC}=\mathrm{CH}\right), 3.32\left(1 \mathrm{H}, \mathrm{CH}^{*}\right.$ of $\mathrm{CHNHCO}), 3.08\left(3 \mathrm{H}, \mathrm{OCH}_{3}^{*}\right), 1.22-0.99\left(7 \mathrm{H}, \mathrm{CH}_{2}^{*} \mathrm{CH}_{2}^{*}, \mathrm{CCH}_{3}^{*}\right)$.

\section{Preliminary kinetic study of 5-fluorouracil derivatives at pH 1.2, pH 7.4:}

The stability of 5 -fluorouracil derivatives was studied in $(0.2 \mathrm{M}) \mathrm{HCl}$ solution $(\mathrm{pH} 1.2)[85 \mathrm{ml}(0.2 \mathrm{M}) \mathrm{HCl}+50 \mathrm{ml}(0.2 \mathrm{M})$ $\mathrm{KCl}$, Distilled water, ad. to $200 \mathrm{ml}]$ and in $(0.1 \mathrm{M})$ phosphate buffer solution $(\mathrm{pH} 7.4)$ [100ml $(0.1 \mathrm{M}) \mathrm{KH} 2 \mathrm{PO} 4+78.2 \mathrm{ml}(0.1$ M) $\mathrm{NaOH}$, Distilled water, ad. to $200 \mathrm{ml}$ ] incubated at $37^{\circ} \mathrm{C}$. The total buffer concentration was $0.1 \mathrm{M}$ and the ionic strength ( $\mu$ ) 1.0 was maintained for each buffer by addition of calculated amount of $\mathrm{NaCl}$. The rate of hydrolysis was followed spectrophotometrically (UV method) by recording the decreases in the absorbance of 5-fluorouracil derivatives accompanying the hydrolysis. The reactions were initiated by adding $1 \mathrm{ml}$ of stock solutions $(1 \mathrm{mg} / \mathrm{ml})$ of the derivatives in methanol to preheated buffer solution at $37^{\circ} \mathrm{C}$ to give final concentration of derivatives $(0.02 \mathrm{mg} / \mathrm{ml})$. The solutions were kept in a water bath at $37^{\circ} \mathrm{C}$ and samples $(3 \mathrm{ml})$ were withdrawn at appropriate time interval $(15,30,60,120$ and $240 \mathrm{~min}$.) and the absorbances were recorded. The observed first rate constants were determined from the slopes of the linear plots of log. concentration remaining versus time [28].

\section{Results and Discussion}

The synthetic pathways for the designed target compounds (III- VI) are illustrated in (scheme 1)

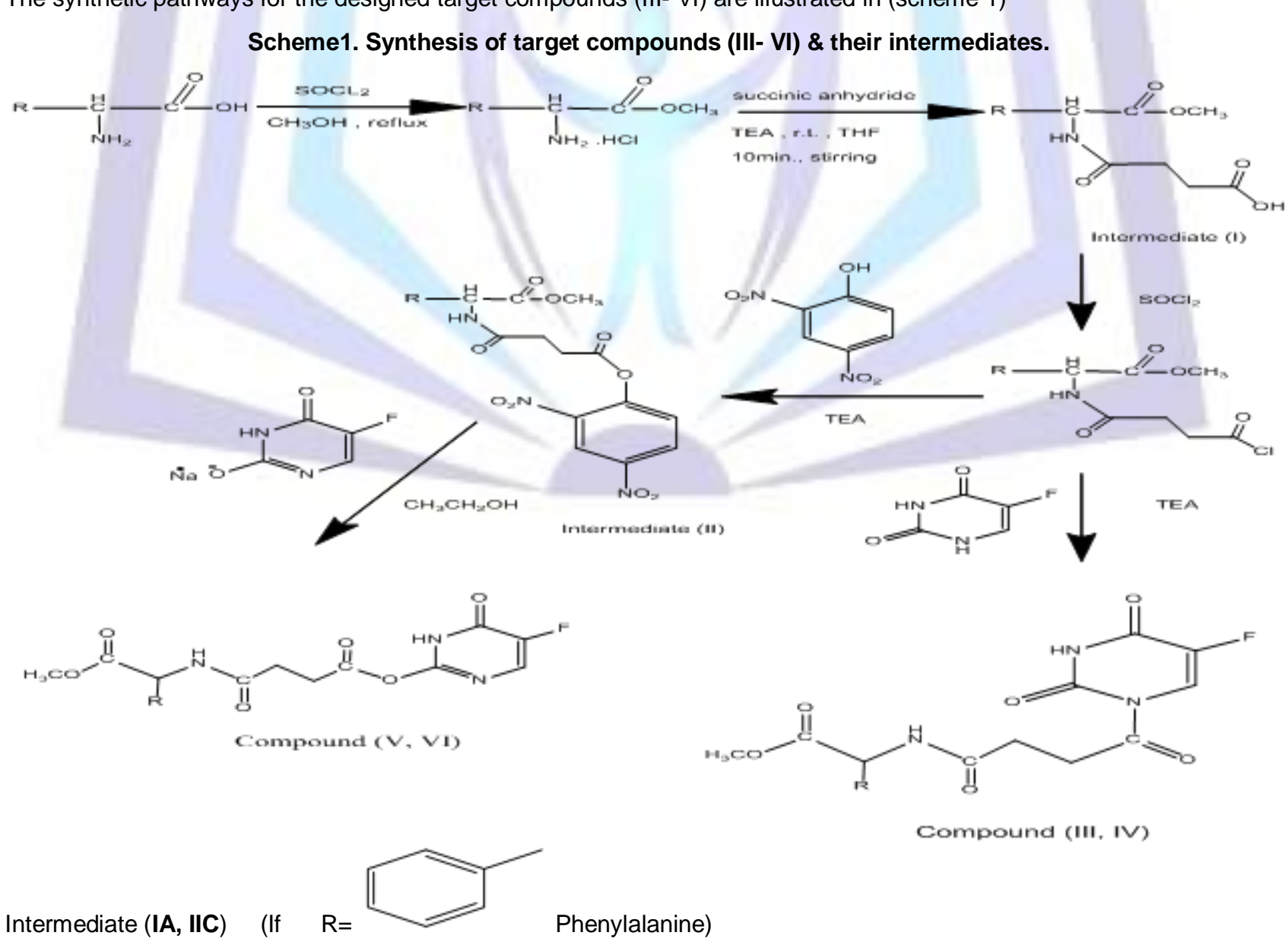

Compound (III, V) 
Intermediate (IB, IID) (if $\quad \mathrm{R}=\mathrm{CH}_{3} \quad$ Alanine)

Compound (IV, VI)

\section{Kinetic study:}

The $\lambda$ max of fluorouracil $265 \mathrm{~nm}$ was the same $\lambda$ max of compounds III, IV, V and VI, but they differ in molar absorpitivity (E) according to the Beer-Lambert equation [29]:

$A=E$ c b ------- equation (1)

Thus making UV method relevant for studying the hydrolysis of these analogues, so the amount of fluorouracil alone was calculated from the following equation [29]:

$A_{T}=E_{R}[R]-E_{R}[P]+E_{P}[P]$------- equation (2)

Where:

$\mathrm{A}_{\mathrm{T}}=$ absorption at any time

$E_{\mathrm{R}}=$ the molar absorpitivity of compound III, IV, V and $\mathrm{VI}$ at $\mathrm{pH} 1.2 \& 7.4$

$[R]=$ the initial concentration of each compound III, IV, V and VI

$E_{\mathrm{P}}=$ the molar absorpitivity of $5-\mathrm{FU}$ at $\mathrm{pH} 1.2 \& 7.4$

$[P]=$ the concentration of $5-F U$

Under experimental conditions used the hydrolysis of the 5-fluorouracil derivatives followed pseudo first order kinetics, since plots of log concentration of 5 -fluorouracil alone vs. time resulted in straight lines, from their slopes; the observed rate constants of hydrolysis were calculated. Figures (1), (2),(3) and (4) are represented graphs for pH stability profile of the compounds III, IV, V and VI respectively; while table (1) shows the $\mathrm{pH}$ values, the corresponding $\mathrm{K}_{\mathrm{obs}}$ and half-life of the hydrolysis of 5-fluorouracil analogues. The half-life was calculated using equation (4), which derives from the first order kinetic law [equation (3)].

log. $C=\log . C_{0}-k t / 2.303$------- equation (3)

$\mathrm{t}_{1 / 2}=0.693 /$ Kobs ------- equation (4)

Table (1) the rate constant of hydrolysis of compounds III, IV, $\mathrm{V}$ and $\mathrm{VI}$ at $\mathrm{pH} 1.2$ and $\mathrm{pH} 7.4$ at $37^{\circ} \mathrm{C}$.

\begin{tabular}{|l|l|l|l|}
\hline compound & $\mathrm{pH}$ & $\mathrm{K}_{\mathrm{obs}}\left(\mathrm{min}^{-1}\right)$ & $\mathrm{t} 1 / 2(\mathrm{~min})$ \\
\hline III & 1.2 & $1.6121 \times 10^{-3}$ & 429.874 \\
& 7.4 & $1.1515 \times 10^{-3}$ & 601.823 \\
\hline \multirow{2}{*}{ IV } & 1.2 & $1.6121 \times 10^{-3}$ & 429.874 \\
\hline & 7.4 & $1.1515 \times 10^{-3}$ & 601.823 \\
\hline V & 1.2 & $2.0727 \times 10^{-3}$ & 334.346 \\
& 7.4 & $1.6121 \times 10^{-3}$ & 429.874 \\
\hline & 1.2 & $1.8424 \times 10^{-3}$ & 376.139 \\
VI & 7.4 & $1.3818 \times 10^{-3}$ & 501.519 \\
\hline
\end{tabular}

One of the crucial requirements for a prodrug is that used, it should show a good stability in aqueous solutions and in gastrointestinal fluid, and it should be readily hydrolyzed following gastrointestinal absorption to release the parent drug [30]. 


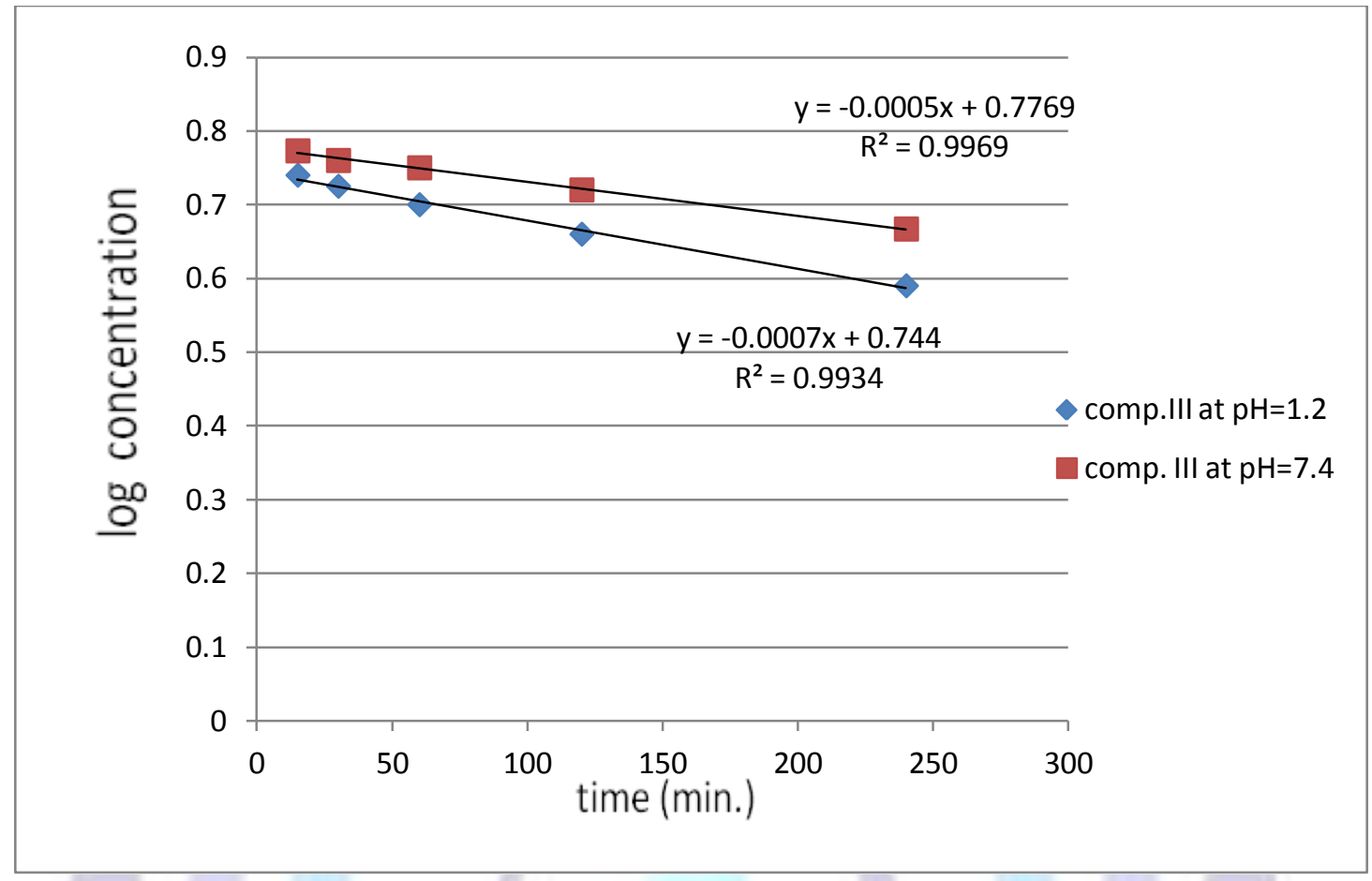

Figure (1) the hydrolysis of compound III in $0.1 \mathrm{M} \mathrm{HCl}$ solution $\left(\mathrm{pH} \mathrm{1.2)}\right.$ and phosphate buffer $(\mathrm{pH} 7.4)$ at $37^{\circ} \mathrm{C}$

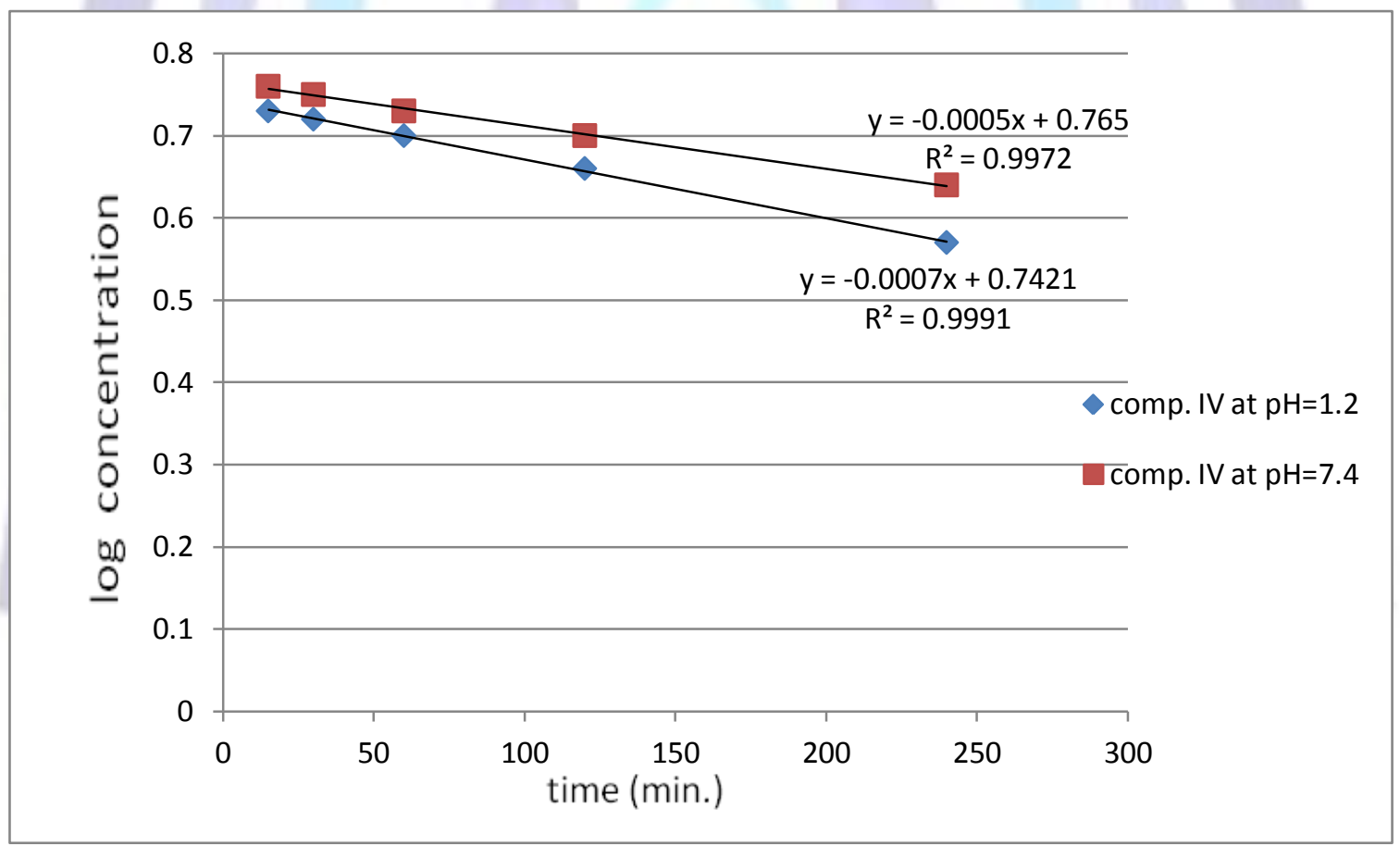

Figure (2) the hydrolysis of compound IV in $0.1 \mathrm{M} \mathrm{HCl}$ solution $(\mathrm{pH} 1.2)$ and phosphate buffer $(\mathrm{pH} 7.4)$ at $37^{\circ} \mathrm{C}$ 


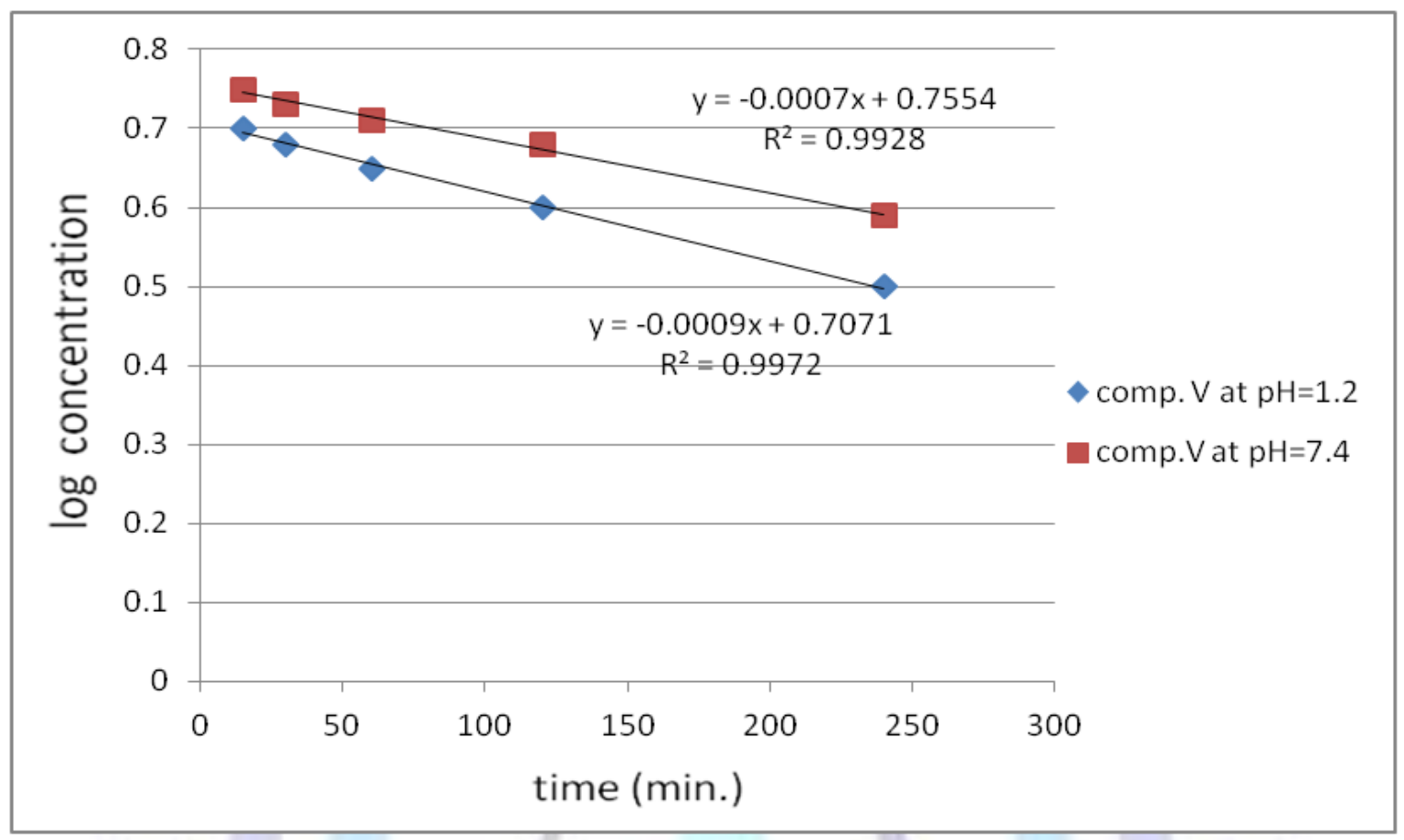

Figure (3) the hydrolysis of compound $\mathrm{V}$ in $0.1 \mathrm{M} \mathrm{HCl}$ solution (pH 1.2) and phosphate buffer $(\mathrm{pH} 7.4)$ at $37^{\circ} \mathrm{C}$

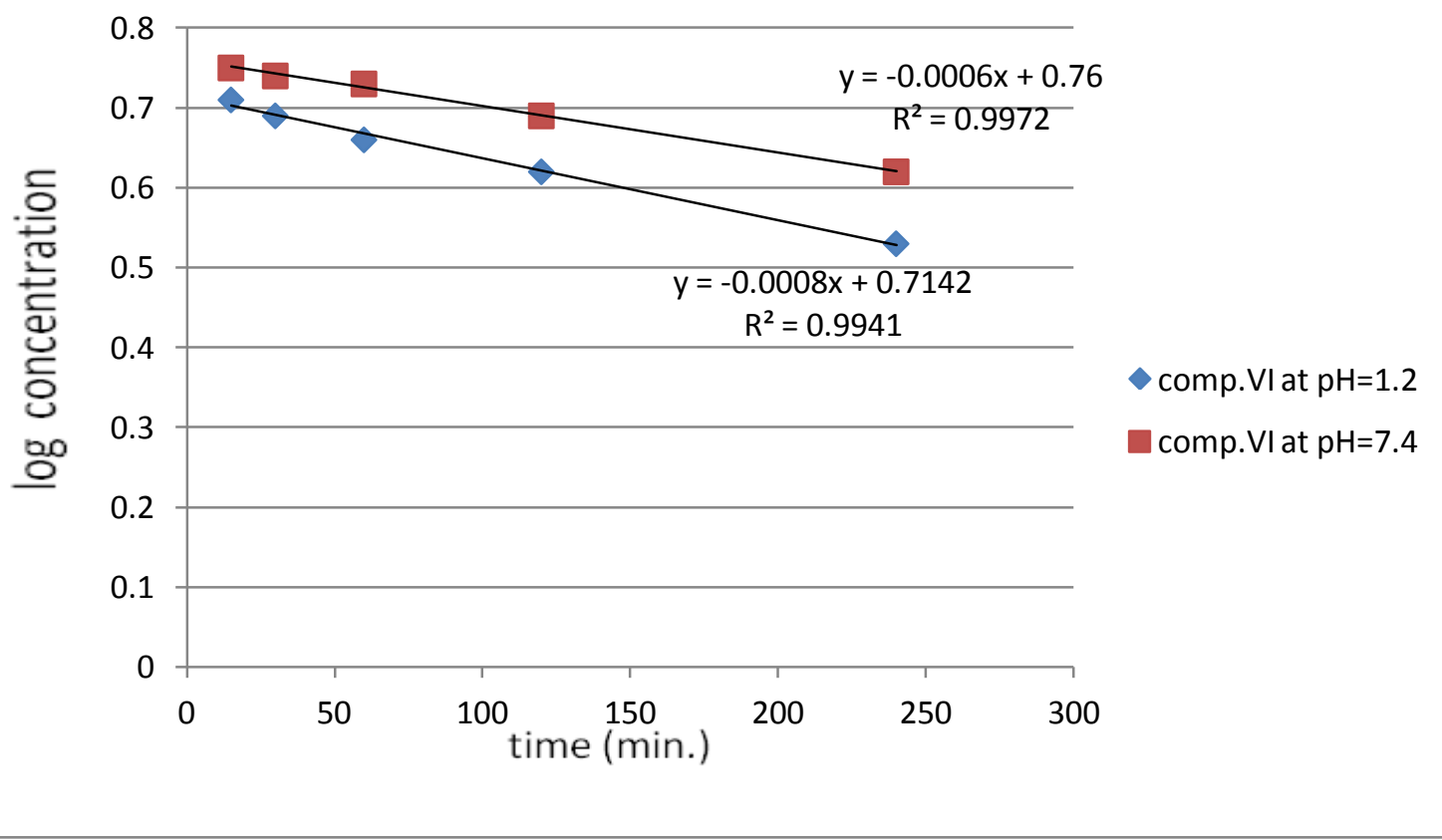

Figure (4) the hydrolysis of compound $\mathrm{VI}$ in $0.1 \mathrm{M} \mathrm{HCl}$ solution (pH 1.2) and phosphate buffer (pH 7.4) at $37^{\circ} \mathrm{C}$

\section{Conclusion:}

The synthetic procedure for the designed target compound was successfully achieved and the structural formula for the synthetic compound was characterized using IR spectroscopy, ${ }^{1} \mathrm{H}-\mathrm{NMR}$, melting points and $\mathrm{R}_{\mathrm{f}}$ values. Preliminary kinetic study for compounds III, IV, V and VI revealed that these compounds were stable at pH 1.2 and pH 7.4. 


\section{References:}

[1] Weitz J, Koch M, Debus J, et al. (2005) .Colorectal cancer. Lancet; 365: 153-165.

[2] Smith, N.F.; Figg, W.D.; Sparreboom, A.,(2004). Recent advances in pharmacogenetic approaches to anticancer drug development. Drug Develop. Res., 62, 233-253.

[3] Ragnhammar, P.; Blomgren, H.A. (1995). How to optimize the effect of 5-fluorouracil modulated therapy in advanced colorectal cancer.Med. Oncol., 12, 187-201.

[4] Zhang, F. M.; Yao, X. J.; Tian, X.; Tu, Y. Q.(2006). Synthesis and Biological Evaluation of New 4 $\beta-5-F u-s u b s t i t u t e d ~ 4 '-$ Demethylepipodophyllotoxin Derivatives. Molecules, 11, 849-857.

[5] Zhang, C. X.; Zhang, Z. B.; Chen, H. M.; Tang, C. C.; Chen, R. Y..(1998). synthesis of 1,2- and 1,3-Cyclic Phospholipid Conjugates of N1-(2-Furanidyl)-N3-(2-hydroxyethyl)-5-fluorouracil. Heteroatom. Chem. 9, 295-298.

[6] Jung, E. Y.; Chung, I. D.; Lee, N. J.; Park, J. S.; Ha, C. S.; Cho, W. J.(2000) Synthesis, Antitumor Activities, and Antiangiogenesis of a Monomer and Its Medium Molecular Weight Polymers:Maleimidoethanoyl-5-fluorouracil and Its Polymers. J. Polym. Sci., Part A: Polym. Chem., 38, 1247-1256.

[7] Lee, J. S.; Jung, Y. J.; Kim, Y. M. (2001).Synthesis and Evaluation of N-Acyl-2-(5-Fluorouracil-1-yl)-D,L-Glycine as a Colon-Specific Prodrug of 5-Fluorouracil. J. Pharm. Sci., 90, 1787-1794.

[8] Albert, A. (1958). Chemical aspects of selective toxicity. Nature, 182, 421-423.

[9] Stella, V.J.; Himmelstein, K.J. (1980). Prodrugs and site-specific drug delivery. J. Med. Chem., 23, 1275-1282.

[10] Kratz, F.; Muller I.A.; Ryppa, C.; Warnecke, A.; Prodrug strategies in anticancer chemotherapy. Chem Med Chem 2008, 3, 20-53.

[11] Haeberline B, Friend DR. (1992). Anatomy and physiology of the gastrointestinal tract: Implications for colonic drug delivery. In: Friend DR, editor., Oral colon specific drug delivery .Boca Raton, FL: CRC Press, , pp. 1-44.

[12] Rudolph MW, Klein S, Beckert TE, Petereit H, Dressman JB. (2001). A new 5-aminosalicylic acid multi-unit dosage form for the therapy of ulcerative colitis. Eur J Pharm Biopharm. , 51, 183-90.

[13] Cavalcanti OA, Van den Mooter G, Caramico-Soares I, Kinget R. (2002). Polysaccharides as excipients for colonspecific coatings. Permeability and swelling properties of casted films. Drug Dev Ind Pharm., 28, 157-164.

[14] Yang L, Chu JS, Fix JA. (2002). Colon-specific drug delivery: new approaches and in vitro/in vivo evaluation. Int J Pharm. 235, 1-15.

[15] Jeong YI, Ohno T, Hu Z, Yoshikawa Y, Shibata N, Nagata S, Takada K. (2001). Evaluation of an intestinal pressurecontrolled colon delivery capsules prepared by a dipping method. J Control Release., 71, 175-182.

[16] Krishnaiah YS, Veer Raju P, Dinesh Kumar B, Bhaskar P, Satyanarayana V. (2001). Development of colon targeted drug delivery systems for mebendazole. J Control Release., 77, 87-95.

[17] Sinha VR, Kumria R. ,(2001). Colonic drug delivery: prodrug approach. Pharm Res., 5, 557-564.

[18] Rubinstein, A. (1995) Approaches and opportunities in colon-specific drug delivery. Crit. Rev. Ther. Drug Carr. Syst. 12, 101-149.

[19] Curini, M.; Epifano, F.; Genovese, S.(2005). Synthesis of a novel prodrug of 3-(4'-geranyloxy-3'-methoxyphenyl)-2trans-propenoic acid for colon delivery. Bioorg. Med. Chem. Lett., 15, 5049-5052.

[20] McLeod AD, Friend DR, Tozer TN. (1993).Synthesis and chemical stability of glucocorticoid-dextran esters: Potential prodrugs for colon-specific delivery. Int J Pharm, , 92:105-114.

[21] Ho DH, Townsend L, Luna MA, Bodey GP.,(1986).Distribution and inhibition of dihydrouracil dehydrogenase activities in human tissues using 5-fluorouracil as a substrate. Anticancer Res, 6,781-784.

[22] Papot, S.; Tranoy, I.; Tillequin, F.; Florent, J.C.; Gesson, J.P. (2002). Design of selectively activated anticancer prodrugs: elimination and cyclization strategies. Curr. Med. Chem. Anticancer Agents, 2, 155-185.

[23] Anil Samleti, Rajesh Kane, Shrinivas Bumrela, Snehal Dhobale and Atul Thite.,(2012). Synthesis and Evaluation of Anti-inflammatory activity of Mutual Prodrugs of Aspirin with Amino Acids. INTERNATIONAL JOURNAL OF PHARMACEUTICAL AND CHEMICAL SCIENCES, Vol. 1 (4), 1343-1349.

[24] Dieter Starke, Kerstin Lischka, Peter Pagles, Eugen Uhlamann, Werner Kramer, Gunter Wess and Ernst Petzinger. (2001). Bile Acid-oligeodeoxynucleotide Conjugates: Synthesis and Liver Excretion in Rats. Bioorganic \& Medicinal Chemistry Letters 11, 945-949.

[25] Atul R. Bendale, Sachin B. Narkhede, Anil G. Jadhav, G. Vidyasagar, (2010). Synthesis and evaluation of some amino acid conjugates of NSAIDS. J. Chem. Pharm. Res., 2(6):225-233. 
[26] Ashutosh Mishra, Ravichandran Veerasamy, Prateek Kumar Jain, Vinod Kumar Dixit and Ram Kishor Agrawal. (2008).Synthesis, Characterization and Pharmacological Evaluation of Amide Prodrugs of Flurbiprofen. J. Braz. Chem. Soc., Vol. 19, No. 1, 89-100.

[27] Mahmoud F. Ibrahim, Hanaa A. Abdel-Reheem, Sherine N. Khattab \& Ezzat A. Hamed, (2013). Nucleophilic Substitution Reactions of 2,4-Dinitrobenzene Derivatives with Hydrazine: Leaving Group and Solvent Effects, International Journal of Chemistry; Vol. 5, No. 3, 33-45.

[28] Ali Basim Talib, Monther F Mahdi and Mohammed H Mohammed, (2010). DESIGN, SYNTHESIS, AND HYDROLYSIS STUDY OF MUTUAL PRODRUGS OF NSAIDS WITH DIFFERENT ANTIOXIDANTS VIA GLYCOLIC ACID SPACER, Pharmacie Globale (IJCP); 12 (07)

[29] Watson, David G: (1999).Ultraviolet and visible spectroscopy: Phamaceutical Analysis. 4: 79.

[30] Uludag, O.; Caliskan, B.; Alkan, A. (2011), Stable ester and amide conjugated of some NSAIDs as analgesic and antiinflammatory compounds with improved biological activity. Turk J chem.; (35) 1-13. 